\title{
DEVELOPMENT AND VALIDATION OF HIGH-PERFORMANCE THIN LAYERCHROMATOGRAPHIC METHOD FOR CIPROFLOXACIN BY QUALITY BY DESIGN APPROACH
}

\author{
SHRADDHA V TATHE ${ }^{1 *}$, MORESHWAR P MAHAJAN ${ }^{1}$, RASHMI G PINJARKAR ${ }^{2}$, ARUN M KASHID ${ }^{2}$ \\ ${ }^{1}$ Department of Pharmaceutical Chemistry, Sinhgad Institute of Pharmacy, Narhe, Pune, Maharashtra, India. ${ }^{2}$ Department of \\ Pharmaceutical Quality Assurance, Sinhgad Institute of Pharmacy, Narhe, Pune, Maharashtra, India. Email: tatheshraddha09@gmail.com
}

Received: 03 July 2021, Revised and Accepted: 23 October 2021

\section{ABSTRACT}

Objective: The aim of this paper is to create a new, systematic high-performance thin-layer chromatography (HPTLC) method for ciprofloxacin that is based on quality by design (QbD).

Methods: The mobile phase was chloroform: IPA: $\mathrm{H}_{2} \mathrm{O}$ : Formic Acid (2:7:0.5:0.5V/V), and the chromatographic separation was performed on aluminum-backed silica gel 60 F254 plates. Ciprofloxacin was detected using UV light at 278nm. In factor screening studies, a 3-factor 17-run standard 3-level factorial design was used, and a Box-Behnken design was used to optimize HPTLC experimental parameters for obtaining anticipated chromatographic conditions. The basic method parameters were tested to understand risk assessment. Three independent parameters, such as saturation time, band duration, and migration distance, were chosen and analyzed based on the risk assessment to see if these three parameters influenced the responses. For ciprofloxacin, the method produces a compact and well-resolved band at $\mathrm{Rf}=0.400 .02$. In the linear regression analysis performed on ciprofloxacin, the regression coefficient was found to be $\mathrm{r} 2=0.996$.

Results: According to the International Council on Harmonization (ICH) guidelines, it was validated for validation parameters such as accuracy, precision, robustness, the limit of detection, and the limit of quantification. The proposed method for ciprofloxacin determination was found to be straightforward, precise, reliable, stable, and sensitive.

Conclusion: The QbD method produced a more robust method that can generate accurate, high-quality, and reliable data during the process, and it can be effectively used in the routine inspection of Ciprofloxacin in the tablets dosage form.

Keywords: Ciprofloxacin, High-performance thin-layer chromatography, Quality by design, Box-Behnken Design.

(C) 2021 The Authors. Published by Innovare Academic Sciences Pvt Ltd. This is an open access article under the CC BY license (http://creativecommons.org/ licenses/by/4.0/) DOI: http://dx.doi.org/10.22159/ajpcr.2021v14i12.42627. Journal homepage: https://innovareacademics.in/journals/index.php/ajpcr

\section{INTRODUCTION}

Ciprofloxacin is a type of antibiotic. Ciprofloxacin is a carboxylic acid that is made up of 1-cyclopropyl-6-fluoro-4-oxo-7-piperazine-1ylquinoline-3-carboxylic acid. Bayer A.G. patented ciprofloxacin in 1983, and it was first used in 1987 [1,2]. Ciprofloxacin is classified as an important medication by the World Health Organization. Ciprofloxacin is classified as essential for human medicine by the WHO. Ciprofloxacin was a generic drug that was available. With over 6 million prescriptions written in 2018, ciprofloxacin was the $109^{\text {th }}$ most widely prescribed drug in the United States. The FDA has approved Ciprofloxacin for urinary tract infections, sexually transmitted infections, bone, and joint infections $[3,4]$.

It's a fluoroquinolone antibiotic with a wide range of action. Ciprofloxacin works against both gram-positive and gram-negative bacteria, inhibiting cell division by inhibiting a type II DNA gyrase and topoisomerase IV, which are needed to distinguish bacterial DNA. Ciprofloxacin can be taken orally or intravenously $[5,6]$. At therapeutic doses, ciprofloxacin's side effects are minor and often consist of gastrointestinal disturbances including nausea and diarrhea [7]. Non-aqueous titration, UV spectrophotometry, colorimetry, high-performance liquid chromatography, HPLC with mass spectroscopy, thin-layer chromatography, gas chromatography, and other methods were used to evaluate it. Non-aqueous titration, UV spectrophotometry, colorimetry, high-performance liquid chromatography, HPLC with mass spectroscopy, thin-layer chromatography, gas chromatography, and capillary electrophoresis were all used to evaluate it $[8,9]$.
In this study, Box-Behnken design was used for the optimization of chromatographic analysis of the HPTLC analysis. This design was decided due to its adaptability to change or include or cross out any parameter at any time when our work is ongoing. This work aimed to develop and validate a quality by a design-based efficient method using HPTLC (Fig. 1) [10].

\section{METHODS}

\section{Chemical and reagents}

Cipla LTD offered a free sample of Ciprofloxacin (Mumbai, India). HiMedica Laboratories PVT LTD was also purchased chloroform (ARGrade) from (India, Mumbai, LTD) E. Merck PVT LTD provided HPTLC plate silica gel 60 F254 (Mumbai India).

\section{Instrumentation}

Methanol was used to prewash HPTLC plates, which were then triggered in a $120^{\circ} \mathrm{C}$ oven for 10 minutes before chromatography. The production was carried out in a $20 \mathrm{~cm} \times 10 \mathrm{~cm}$ twin through glass chamber with chloroform, isopropyl alcohol, water, and formic acid (2:7:0.5:0.5 v/v) as the mobile step and a development distance of $80 \mathrm{~mm}$ after 10 minutes of saturation with mobile vapor. The chromatography plates were dried with an air dryer after growth, and for the current analytical analysis, a CAMAG (Muttenz, Switzerland) HPTLC device with a CAMAG LINOMAT sample applicator, a Hamilton syringe (Bonduz, Switzerland), and a CAMAG TLC Scanner with WINCATS software was used.

\section{Preparation of standard stock solution}

The study was to make the stock solution, dissolve $5 \mathrm{mg}$ in $10 \mathrm{ml}$ methanol to obtain a concentration of 5001 
Selection of analytical wavelength

The bands were scanned over a range of 400-200 nm after chromatographic development, and a wavelength of $278 \mathrm{~nm}$ was reached, which was used to detect method development and validation.

\section{Method development as per experimental design}

The Ishikawa fishbone diagram was created using Microsoft Excel at the start of the risk assessment plan to structure the risk operation plan for the factors that influence the system $[11,12]$. Critical analytical attributes (CAAs) 17 were studied using a standard 3-factorial design to determine the critical system parameters/critical process parameters that primarily affect the CAAs (saturation time, band length, migration distance) $[13,14]$. Using the software suggested in Table 1, the design matrix enrolled considered factors and their low, medium, and high levels. The experimental design runs were analyzed for the influence of the study factors on the CAAs.

CMPs, particularly saturation time, band length, and migration distance, were studied at three levels, namely low, medium, and high, using the box-Behnken design. According to the Box-Behnken design, a design matrix consists of 17 experimental runs. The mathematical software Design-Expert version 11 was used to evaluate all of the findings.

\section{RESULTS AND DISCUSSION}

\section{Optimization and data analysis}

Design-expert software version 11 was used to optimize data analysis by choosing a quadratic model for detecting retardation factor. For CAAs (as given in Fig. 2), the 3D response surface plot was observed, as well as the product of the model's analysis of variance (ANOVA) for the Rf value of the ciprofloxacin chromatogram. The model's estimation of<smiles>O=C(O)c1cn(C2CC2)c2cc(N3CCNCC3)c(F)cc2c1=O</smiles>

Fig. 1: Ciprofloxacin structure the Rf value was statistically important, as shown by a probability value of less than 0.05 . For the Rf value responses, all quadratic terms were found to be meaningful.

With a saturation time of 10 minutes, a band length of $0.4 \mathrm{~mm}$, and a migration distance of $80 \mathrm{~cm}$, the numerical optimization indicated optimal conditions (Table 2 and Figs. 2-4).

\section{Method validation}

According to the International Council of Harmonization (ICH) guidelines, the existing method was validated for linearity, accuracy (percent recovery), precision, robustness, the limit of detection (LOD), and the limit of quantification (LOQ).

\section{Linearity}

For ciprofloxacin, the typical calibration curve was plotted in a concentration range of 50-300 ng per band, respectively. The coefficient

Table 1: Design matrix as per Box-Behnken for optimization of the HPTLC method

\begin{tabular}{llll}
\hline Run & $\begin{array}{l}\text { (A) Saturation } \\
\text { time }(\mathbf{m i n})\end{array}$ & $\begin{array}{l}\text { (B) Band } \\
\text { length } \mathbf{( m m})\end{array}$ & $\begin{array}{l}\text { (C) Migration } \\
\text { distance } \mathbf{( c m})\end{array}$ \\
\hline 1 & 10 & 4 & 70 \\
2 & 5 & 8 & 80 \\
3 & 15 & 8 & 80 \\
4 & 5 & 6 & 70 \\
5 & 15 & 6 & 90 \\
6 & 15 & 6 & 70 \\
7 & 10 & 6 & 80 \\
8 & 5 & 6 & 90 \\
9 & 15 & 4 & 80 \\
10 & 10 & 6 & 80 \\
11 & 10 & 6 & 80 \\
12 & 5 & 4 & 80 \\
13 & 10 & 8 & 70 \\
14 & 10 & 6 & 80 \\
15 & 10 & 4 & 90 \\
16 & 10 & 6 & 80 \\
17 & 10 & 8 & 90 \\
\hline
\end{tabular}

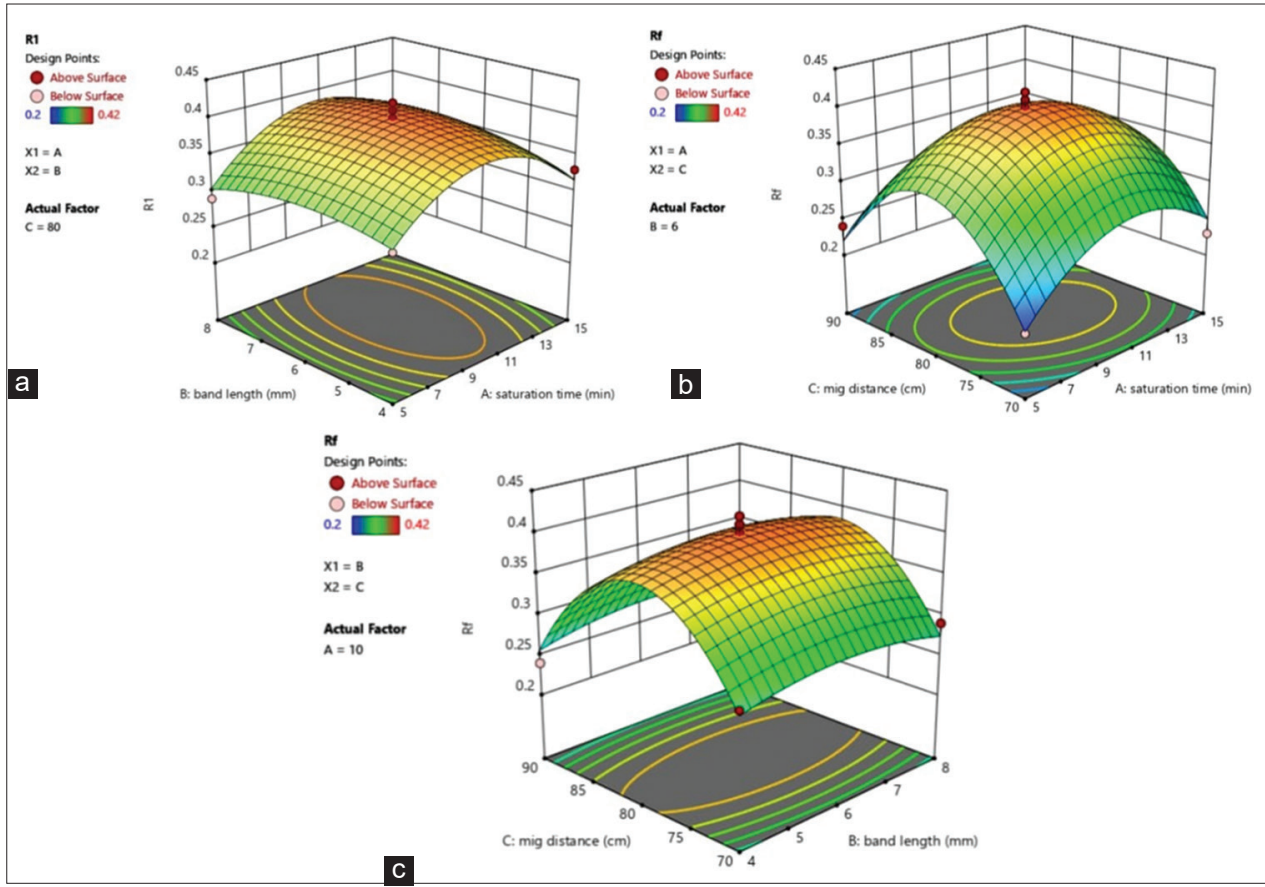

Fig. 2: 3D response surface plots of Ciprofloxacin (a) showing of band length and saturation time on the rf value, (b) the influence of migration distance and saturation time on rf value, (c) the influence of migration distance and band length on the rf value 
values for the used linearity spectrum were strong $\left(r^{2}=0.996\right)$. For ciprofloxacin, the linear regression equations were found to be $y=769.969 x+533.278$. The linearity calibration curves are shown in Fig. 5.

\section{Precision}

The \%RSD values for ciprofloxacin intra-day were found to be 0.38 , respectively. The \% RSD values for ciprofloxacin inter-day were found to be 1.33 , respectively $(<2)$.

\section{Robustness}

The standard deviation of areas was calculated for each condition and $\%$ RSD was less than $2 \%$. The result of robustness is shown in the following Table 3 .

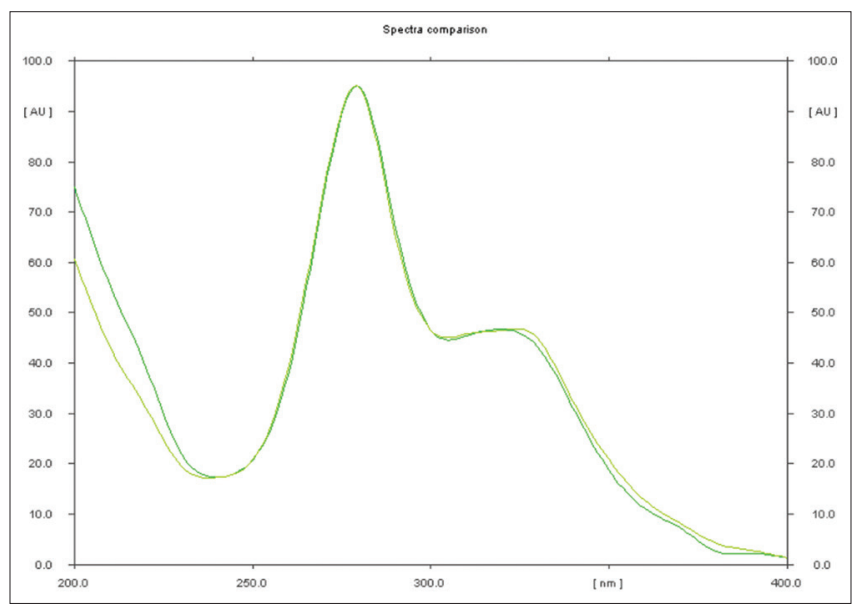

Fig. 3: Overlaid spectra of ciprofloxacin

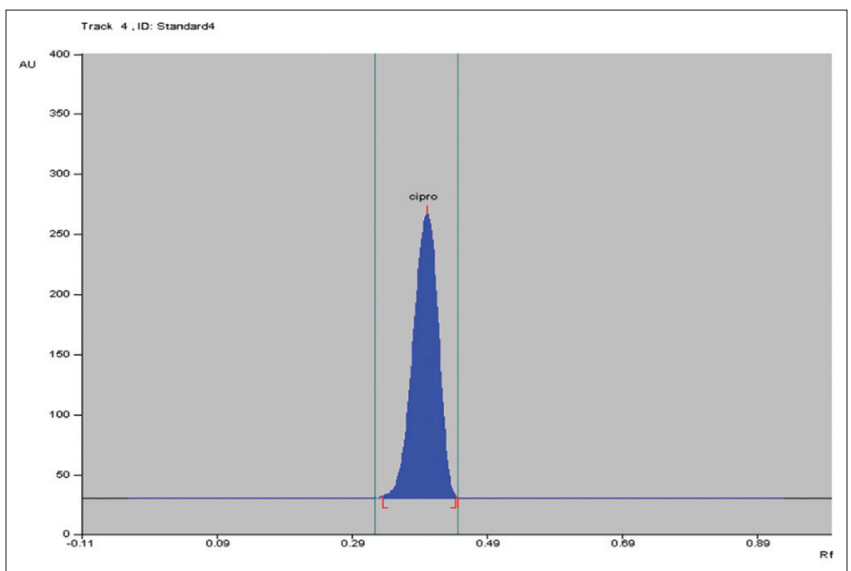

Fig. 4. Typical chromatogram of ciprofloxacin

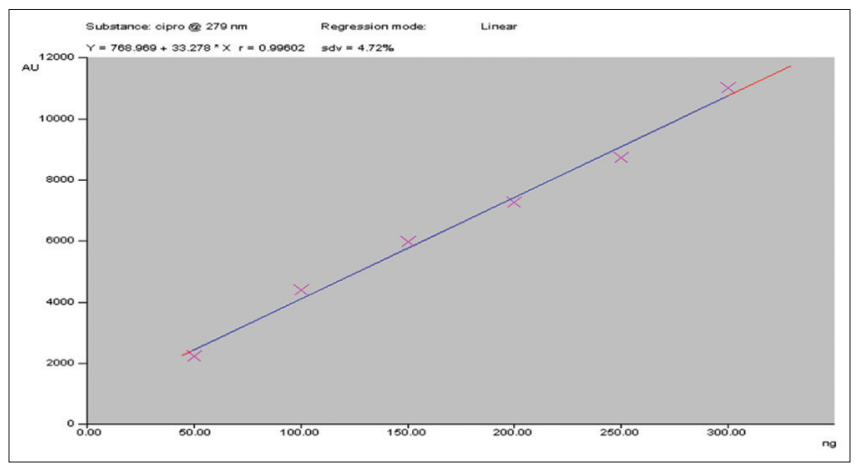

Fig. 5: Linearity of ciprofloxacin
Accuracy

The experiment's precision was determined by spotting a drug standard solution over the pre-analyzed sample solution. The recovery research was conducted at three different levels: $80 \%, 100 \%$, and 120 percent. Table 4 displays the outcome.

\section{Limit of detection and limit of quantification}

The developed method's LOD and LOQ for ciprofloxacin were found to be 24.98 and $75.69 \mathrm{ng}$ per band, respectively, indicating the proposed method's sensitivity. Table 5 displays the LOD and LOQ data.

Table 2: Results of analysis of ANOVA (ciprofloxacin)

\begin{tabular}{lllllll}
\hline Responses & SS & DF & MS & F-value & p-value & Results \\
\hline Rf & 0.0823 & 9 & 0.0091 & 22.67 & 0.0002 & Significant \\
\hline
\end{tabular}

RF: Retention factor, SS: Sum of squares, DF: Degree of freedom, MS: Mean square

\section{Table 3: Robustness study}

\begin{tabular}{ll}
\hline Robustness & \%RSD \\
\hline Mobile phase composition $( \pm 0.1 \mathrm{ml})$ & 0.78 \\
Saturation time $( \pm 5$ min $)$ & 1.17 \\
Development to scanning $( \pm 5 \mathrm{~min})$ & 0.99 \\
Volume of the mobile phase $( \pm 1 \mathrm{ml})$ & 0.28 \\
Spotting to development $( \pm 5 \mathrm{~min})$ & 1.16 \\
\hline
\end{tabular}

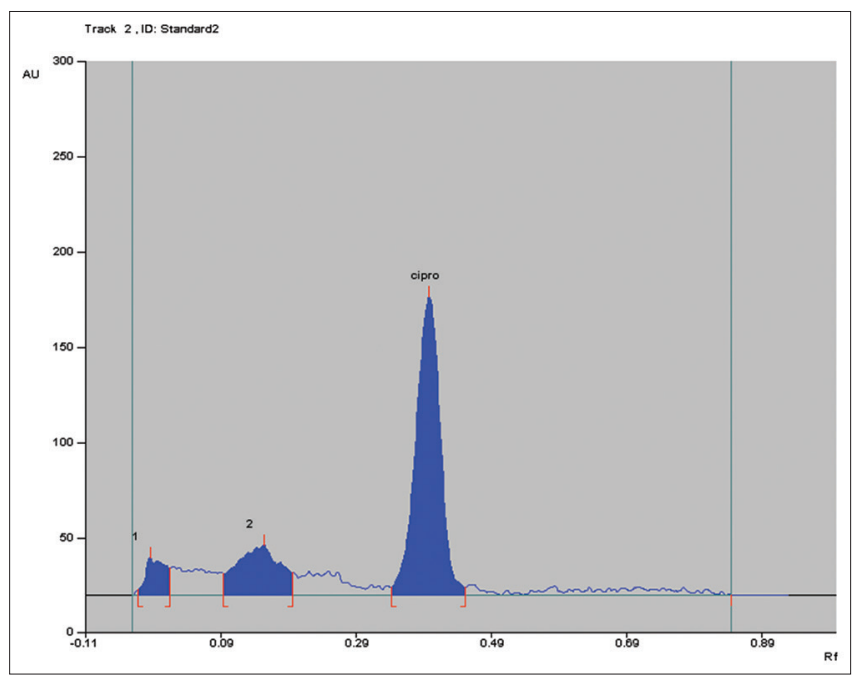

Fig. 6: Densitogram of alkali $(0.1 \mathrm{~N} \mathrm{NaOH})$ treated sample.

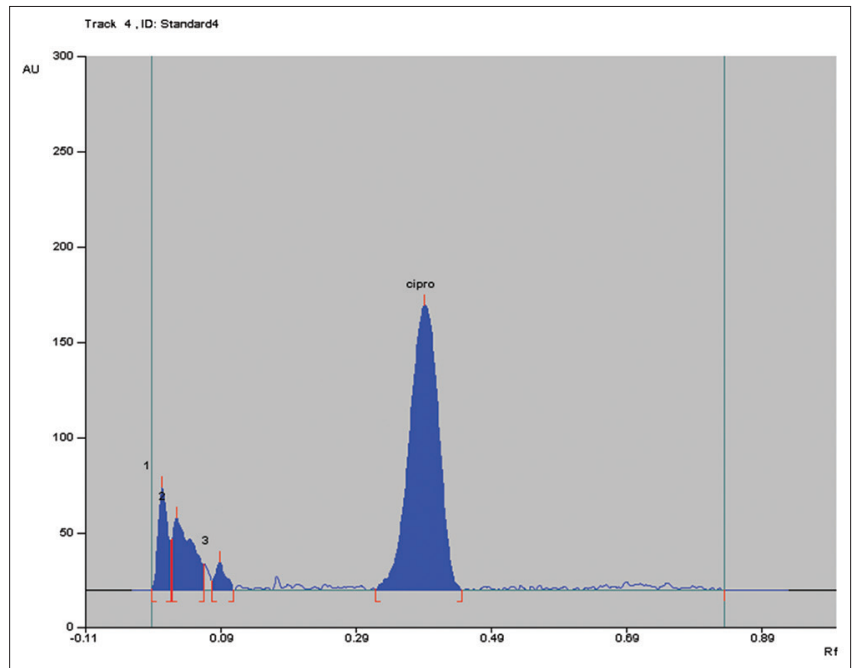

Fig. 7: Densitogram of the sample exposed to heat 
Table 4: Recovery data for ciprofloxacin

\begin{tabular}{llllll}
\hline Drug & $\begin{array}{l}\text { Recovery } \\
\text { level [\%] }\end{array}$ & $\begin{array}{l}\text { Initial } \\
\text { amount [mg] }\end{array}$ & $\begin{array}{l}\text { Initial contact. } \\
\text { [ng per band } \\
\text { length] }\end{array}$ & $\begin{array}{l}\text { Amount added } \\
\text { [mg] }\end{array}$ & $\begin{array}{l}\text { Amount of drug } \\
\text { recovered }\end{array}$ \\
\hline \multirow{3}{*}{ Ciprofloxacin } & 80 & 5 & 200 & 4 & 3.93 \\
& 100 & 5 & 200 & 5 & 5.03 \\
6.05 & 68.25 \\
\hline
\end{tabular}

Table 5: Summary of linear regression and validation data

\begin{tabular}{ll}
\hline Parameters & Ciprofloxacin \\
\hline Linearity range [ng per band] & $50-300$ ng per band \\
Linear regression equation & Y $=769.969 \mathrm{x}+533.278$ \\
Slope & 769.969 \\
Y-intercept & 533.278 \\
Correlation coefficient & 0.996 \\
Limit of detection (ng per band) & 24.98 \\
Limit of Quantification (ng per band) & 75.69 \\
System precision (\% RSD) & 0.48 \\
Intra-day (\% RSD) & 0.38 \\
Inter-day (\% RSD) & 1.33 \\
\hline
\end{tabular}

Table 6: Observation table

\begin{tabular}{ll}
\hline Conditions & Degradation (\%) \\
\hline $0.1 \mathrm{~N} \mathrm{NaOH}($ room temp for $1 / 2 \mathrm{~h})$ & $6.45 \%$ \\
$0.1 \mathrm{~N} \mathrm{HCL} \mathrm{(room} \mathrm{temp} \mathrm{for} 1 / 2 \mathrm{~h})$ & $8.39 \%$ \\
$3 \% \mathrm{H}_{2} \mathrm{O}_{2}$ (room temp for $\left.1 / 2 \mathrm{~h}\right)$ & $6.96 \%$ \\
$\mathrm{H}_{2} \mathrm{O}(1 / 2 \mathrm{~h})$ & $9.43 \%$ \\
Dry heat $40^{\circ} \mathrm{C}$ for $30 \mathrm{~min}$ & $7.28 \%$ \\
UV light for $24 \mathrm{~h} 254 \mathrm{~nm}$ & $8.29 \%$ \\
\hline
\end{tabular}

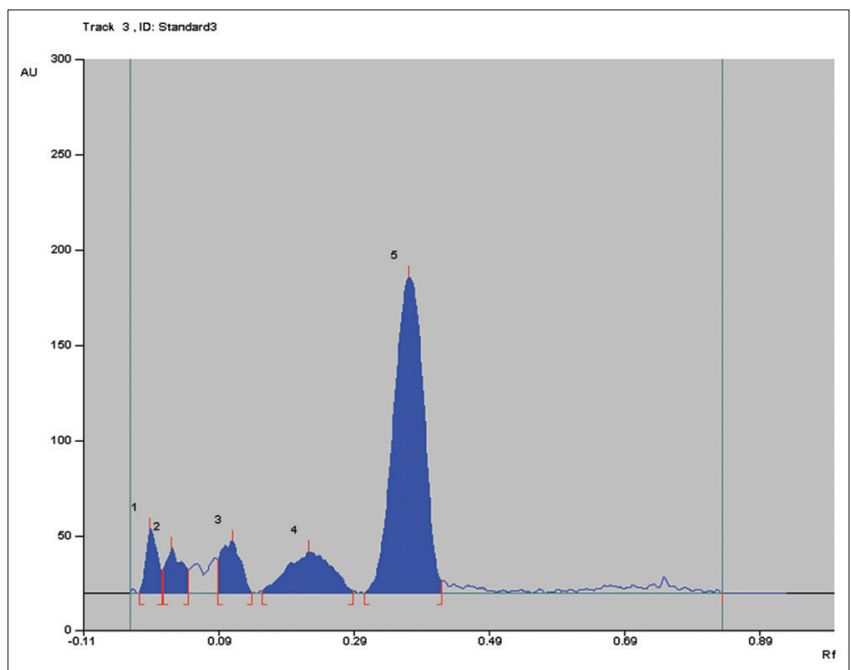

Fig. 8: Densitogram of the sample exposed to UV radiations

Stress degradation study

Significant degradation of ciprofloxacin was observed under neutral hydrolysis conditions. While lesser degradation was observed under alkaline hydrolysis and oxidative condition. 6.45\% degradation was observed for ciprofloxacin in alkaline hydrolysis ( $3 \mathrm{ml}$ in $0.1 \mathrm{~N} \mathrm{NaOH}$ ) after keeping it at room temperature for $1 / 2 \mathrm{hrs}$. Ciprofloxacin showed oxidative degradation at room temperature for $1 / 2 \mathrm{~h}$ of about $6.96 \%$. Ciprofloxacin showed degraded product peaks at Rf 0.41 and 0.89 under dry heat (oven $40^{\circ} \mathrm{C} 30 \mathrm{~min}$ ). Ciprofloxacin was found to be degraded up to $7.28 \%$ with a decrease in an area only. Photolytic studies were also carried out by exposure of the drug to UV light for $24 \mathrm{~h}$ on 254 (Table 6 and Figs. 6-11).

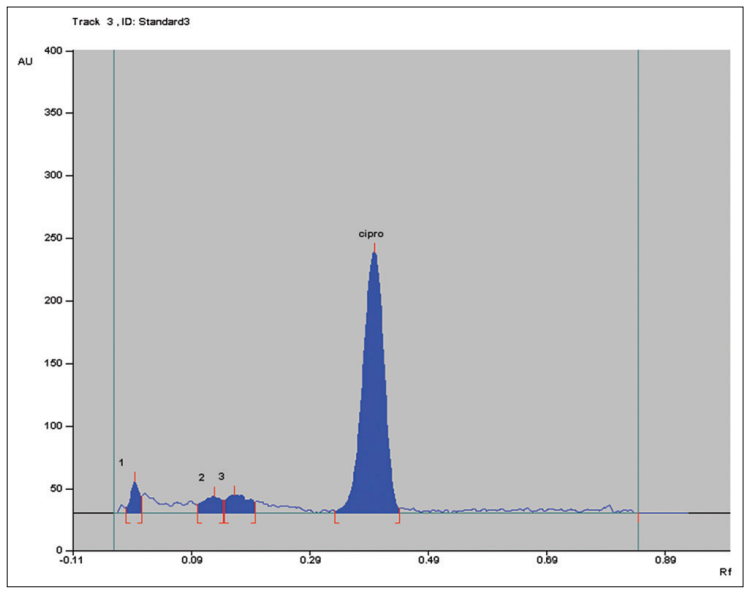

Fig. 9: Densitogram of acid (0.1 N HCL) treated sample

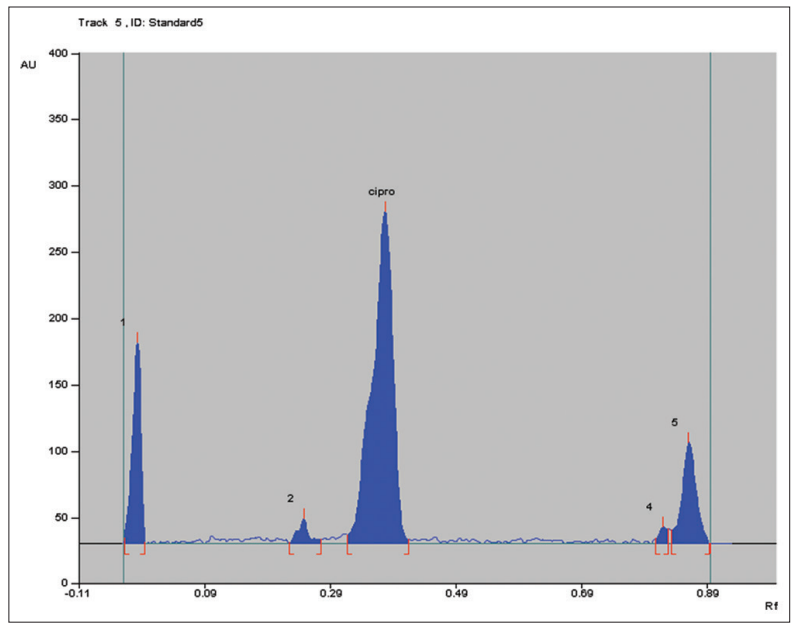

Fig. 10: Densitogram of the sample exposed to neutral hydrolysis

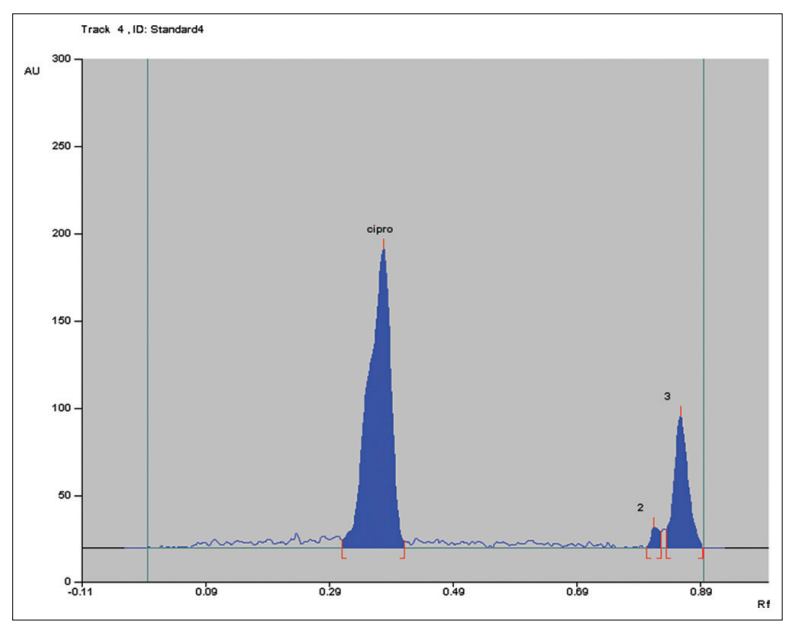

Fig. 11: Densitogram of oxide $\left(3 \% \mathrm{H}_{2} \mathrm{O}_{2}\right)$ treated sample 


\section{CONCLUSION}

The box-Behnken design and response surface methodology are useful tools for determining the sensitivity of ciprofloxacin $\mathrm{Rf}$ values to various chromatographic variables. Using a useful experimental design method, the saturation period, band duration, and migration distance were all optimized at the same time. It is a cost-effective method for generating a large volume of data in a short amount of time with a limited number of experiments. The proposed method for ciprofloxacin determination was found to be straightforward, precise, reliable, stable, and sensitive. The $\mathrm{QbD}$ method produced a more robust method that can generate accurate, high-quality, and reliable data during the process.

\section{ACKNOWLEDGMENT}

The authors are thankful to Sinhgad College of Pharmacy (Pune, India) and Sophisticated Analytical Instrument Facility (Dr. D.Y. Patil Pimpri, Pune, India) for providing the necessary facilities to carry out this work.

\section{AUTHOR CONTRIBUTION}

RP studied and carry out the research work. RP and AG wrote the manuscript and ST and AK checked and finalized the manuscript.

\section{CONFLICT OF INTREST}

The authors declared that they have no conflict of interest.

\section{AUTHOR FUNDING}

No found was received by any agency.

\section{REFERENCES}

1. Bera AK, De Amit K. RP-HPLC method development and validation for the determination of ciprofloxacin from marketed tablet dosage forms. J Chem Pharm Res 2014;6:1214-8.

2. Krishna JR, Naga B, Sandhya SH. Development and validation of
RP-HPLC method for the simultaneous estimation of ciprofloxacin hydrochloride and ornidazole in combined pharmaceutical dosage form. J Adv Pharm Educ Res 2014;4:440-3.

3. Ali SA, Mmuo CC, Abdulraheem RO and Abdulkareem SS. High performance liquid chromatography (HPLC) Method development and validation indicating assay for ciprofloxacin hydrochloride. J Appl Pharm Sci 2011;1:239.

4. Wu SS, Chein CY, Wen YH. Analysis of ciprofloxacin by a simple highperformance liquid chromatography method. J Chrom Sci 2008;46:490-5.

5. Vishnuraj AR, Gurupadayya BM, Kathirvel S. Stability indicating analytical method development and validation of ciprofloxacin by RPHPLC with fluorescence detector. Int J Pharm Qual Ass 2021;12:51-6.

6. Karunasree A, Thejomoorthy K, Jaffer M, Padmanabha RY, Ramalingam P. In vitro protein binding study of ciprofloxacin by new UV-spectrophotometric method. Int J Pharm Technol Res 2010;2:1150-4.

7. Nijhu RS, Jhanker YM, Sutradhar KB. Development of an assay method for simultaneous determination of ciprofloxacin and naproxen by UV spectrophotometric method. Stam J Pharma Sci 1970;4:84-90.

8. Novakovic J, Nesmerak K, Nova H, Filka K. An HPTLC method for the determination and the purity control of ciprofloxacin HCL in coated tablets. J Pharm Biomed Anal 2001;25:957-64.

9. Maya MT, Gonçalves NJ, Silva NB, Morais JA. Simple highperformance liquid chromatographic assay for the determination of ciprofloxacin in human plasma with ultraviolet detection. J Chromatogr B Biomed Sci Appl 2001;755:305-9

10. Ali J, Pramod K, Tahir M, Charoo N, Ansari S. Pharmaceutical product development: A quality by design approach. Int J Pharm Investig 2016;6:129.

11. Bezerra MA, Santelli RE, Oliveira EP, Villar LS, Escaleira LA. Response surface methodology (RSM) as a tool for optimization in analytical chemistry. Talanta 2008;76:965-77.

12. Ferreira SL. Box-Behnken design: An alternative for the optimization of analytical methods. Anal Chim Acta 2007;597:179-86

13. Fukuda IM, Pinto CF, Moreira CS, Saviano AM, Lourenço FR. Design of experiments (DoE) applied to pharmaceutical and analytical quality by design (QbD). Braz J Pharm Sci 2018;54:e01006.

14. Vogt FG, Kord AS. Development of quality-by-design analytical methods. J Pharm Sci 2011:100:797-812. 